\title{
Mitigation of variability between competitively fed dairy cows through increased feed delivery frequency
}

\author{
R. E. Crossley, A. Harlander-Matauschek, and T. J. DeVries ${ }^{1}$ \\ Department of Animal Biosciences, University of Guelph, 50 Stone Rd East, Guelph, ON, N1G 2W1, Canada
}

\begin{abstract}
The objective of this study was to determine whether increased frequency of total mixed ration (TMR) delivery could mitigate the effects of feed bunk competition on the behavior and productivity of individual lactating dairy cows within a group. We hypothesized that, for competitively fed cows, a greater frequency of TMR delivery would improve access to feed, and reduce individual variability in behavior, meal patterns, and production between cows. Sixteen lactating Holstein dairy cows (first lactation $=4$, second lactation $=5, \geq$ third lactation $=7$ ) averaging $72 \pm 35 \mathrm{~d}$ in milk and producing $42 \pm 6 \mathrm{~kg}$ of milk/d at the start of the trial, were categorized as either young ( $\leq$ second lactation) or mature ( $\geq$ third lactation) and paired to maximize difference in parity. Pairs were housed 4 at a time and competitively fed a TMR at a ratio of 2 cows: 1 feed bin. Cow pairs were exposed, in a crossover design, to each of 2 feed delivery frequency treatments: low $(2 \times / d)$ and high $(6 \times / d)$ frequency. Treatments were applied for $10 \mathrm{~d}$, with dry matter intake (DMI), feeding behavior (feeding time, feeding rate, and meal patterns), and replacement frequency for each cow recorded using an automated feed intake system on d 6 to 10 of each period. Rumination time, feed sorting, lying behavior, and productivity were also measured for this period. Variability in behavior within pairs of cows was determined by averaging the absolute difference within each pair over the recording period to provide 1 value per pair. Frequency of TMR delivery did not affect feeding time, feeding rate, DMI, replacement frequency, feed sorting, or productivity. At the high delivery frequency, there was a tendency for rumination time to increase $[$ low $=519.3 ;$ high $=544.3 \mathrm{~min} / \mathrm{d}$; standard error of the difference $(\mathrm{SED})=11.32]$, and to be more variable within pairs $($ low $=38.0$, high $=50.0 \mathrm{~min} / \mathrm{d} ;$ SED $=$ 5.57). Cows also had longer lying bouts at the high delivery frequency $($ low $=53.0$; high $=55.5 \mathrm{~min} /$ bout;
\end{abstract}

Received March 24, 2017.

Accepted August 25, 2017.

${ }^{1}$ Corresponding author: tdevries@uoguelph.ca
$\mathrm{SED}=1.00)$. No differences in daily meal patterns were found between treatments; however, the average first meal following each feeding indicated that cows under the high delivery frequency spent less time, consuming smaller meals during peak feeding periods. Comparing the young and mature individuals within each treatment pair revealed that feeding rate (young $=0.16$; mature $=0.19 \mathrm{~kg} / \mathrm{min} ; \mathrm{SED}=0.014$ ) and DMI (young $=25.6$; mature $=28.6 \mathrm{~kg}$ of $\mathrm{DM} / \mathrm{d} ; \mathrm{SED}=1.36)$ were lower for the young cows on both treatments. Meal frequency was greater in young cows (young $=9.0$; mature $=7.5$ meals $/ \mathrm{d} ; \mathrm{SED}=0.71$ ) and meal size was greater in mature cows (young $=3.2$; mature $=4.2 \mathrm{~kg}$ of DM/ meal; SED $=0.32$ ) across treatments. These results suggest that for cows fed at a high level of competition, increasing TMR delivery frequency from 2 to $6 \times / \mathrm{d}$ led to consumption of shorter, smaller meals during peak periods of feed consumption. However, under these conditions, the relative parity of competitively fed cows had a greater effect on feeding behavior, meal patterns, and production than did the frequency of feed delivery. Key words: competition, behavior, feed frequency, meal pattern

\section{INTRODUCTION}

Feeding a TMR 1 to 2 times daily is common practice on many farms, yet because the delivery of fresh feed has been shown to have the greatest influence in stimulating feeding activity in dairy cattle (DeVries and von Keyserlingk, 2005; King et al., 2016b), there has been a great deal of research into the effects of greater frequency of TMR delivery. Studies of feed delivery frequency have commonly investigated increases up to 2×/d (Kudrna, 2003; Greter et al., 2013), 3×/d (Hart et al., 2014), $4 \times / \mathrm{d}$ (Phillips and Rind, 2001; DeVries et al., 2005), 5×/d (Mäntysaari et al., 2006), and $12 \times / d$ (French and Kennelly, 1990) over the baseline of 1 to $2 \times /$ d. Greater and more evenly distributed feeding activity throughout the day (Phillips and Rind, 2001; DeVries et al., 2005) as well as decreased sorting of feed (DeVries et al., 2005) have both been demonstrated with increased frequency of TMR delivery. The provision of fresh feed throughout the day is a contributing factor 
to a healthy rumen environment (Nocek and Braund, 1985); thus, more consistent availability of TMR could aid in the prevention of SARA (Shaver, 2002; Krause and Oetzel, 2006) and promote greater milk production efficiency (Mäntysaari et al., 2006) and improved milk fat production (Gibson, 1984).

Researchers have yet to establish how increased feed delivery frequency affects the behavior (such as feeding patterns, rumination activity, and lying time) of dairy cows in a competitive feeding environment. Competition for feed access can lead cows to modify their feeding behavior, including reduced feeding time, and increased rate of feed intake, meal size, and idle standing time (Olofsson, 1999; Huzzey et al., 2006; Hosseinkhani et al., 2008), all of which may elevate the risk of health problems such as lameness and SARA (Cook et al., 2004). Subordinate cows, in particular, have been shown to adjust their feeding times away from peak periods associated with fresh feed delivery, to avoid the social stress and agonistic behavior resulting from competition for feed access (Olofsson, 1999; RiojaLang et al., 2009). This, potentially, leads those cows to consume an unbalanced ration of poorer nutritional quality, due to the preferential selection of feed in the bunk throughout the day (Leonardi and Armentano, 2007; Hosseinkhani et al., 2008). DeVries et al. (2005) demonstrated this change in nutrient content of sorted feed throughout the day; further, consumption of such feed may lead to reduced milk components and efficiency of milk production (Miller-Cushon and DeVries, 2017). Lower-parity animals may experience the greatest impact, as their young age and smaller size makes them more likely to be subordinate to other individuals within the herd (Dickson et al., 1970; Wierenga, 1990). More frequent feed delivery may reduce variability between individual cows, as it is those animals that experience shorter feeding times under less frequent feed delivery that are observed to increase their feed consumption activity during peak periods, with more frequent feed deliveries (DeVries et al., 2005).

The primary objective of this study was, thus, to determine whether increased feeding stimuli could mitigate the effects of competition on individual cows within a group. A secondary objective was to examine whether individual cows of different parity would be affected in the same manner. We hypothesized that, in competitive feeding situations, (1) a higher frequency of TMR delivery would allow more individuals the opportunity to access feed during peak periods of feeding activity than at a lower frequency of TMR delivery, and (2) there would be less variability in feeding patterns, behavior, and productivity between individual cows at a higher TMR delivery frequency than at a lower TMR delivery frequency.

\section{MATERIALS AND METHODS}

\section{Animals and Housing}

Sixteen lactating Holstein dairy cows, consisting of 4 first-lactation, 5 second-lactation, and 7 third-lactation or greater (parity $=4 \pm 0.8$ ) animals, were selected from the University of Guelph, Kemptville Campus Dairy Education and Innovation Center herd. Selected individuals had an average DIM of $72 \pm 35 \mathrm{~d}$, daily production of $42 \pm 6 \mathrm{~kg} / \mathrm{d}$, and $\mathrm{BW}$ of $692 \pm 73 \mathrm{~kg}$ at entry to the study. Before selection, the health status of each cow was evaluated and no cows were included that experienced health concerns during the transition period or early lactation.

Cows were housed in groups of 8 in a freestall pen with a stocking density of 1 stall/cow. Stalls were equipped with waterbeds (DCC Waterbeds; Advanced Comfort Technology Inc., Reedsburg, WI) and bedded with wood shavings as needed; manure was scraped from stalls manually to within range of the alley scrapers at milking times. Two water bowls within the pen provided cows with ad libitum access to water. Cows were milked $3 \times / \mathrm{d}$ at 0715,1430 , and $2000 \mathrm{~h}$. For milking, cows were brought manually to a holding pen and milked individually and sequentially using an automated milking system (AMS; Lely Astronaut A3 Next; Lely Industries N.V., Maassluis, the Netherlands) to represent conventional milking practices. Cows spent a maximum of $3.5 \mathrm{~h} / \mathrm{d}$ outside the pen for milking. The cows did not receive supplemental feed from the AMS; TMR (Table 1) was provided through automated feed bins (Insentec RIC; Marknesse, the Netherlands) that monitored the intakes and timing of feed visits for each individual animal, as validated by Chapinal et al. (2007).

Cows were managed according to the standard operating procedures of the research facility. Once weekly, cows' feet were treated with a preventative hoof spray (10\% solution of Hoofsure; Provita Eurotech Ltd., Omagh, UK). The use of cows and experimental procedures complied with the guidelines of the Canadian Council on Animal Care (CCAC, 2009) and were approved by the University of Guelph Animal Care Committee (Animal Use Protocol \#3245).

\section{Experimental Design}

The study took place in July and August 2015 and utilized 8 pairs of cows (16 cows divided into 2 groups of 4 pairs each) in a $2 \times 2$ crossover design. Sample size and power analyses were used to calculate the number of replicates (pairs) needed (Morris, 1999) to detect a $12.5 \%$ level of observed difference for the primary 
Table 1. Ration ingredients (\% of DM) and chemical composition (\% of DM unless otherwise noted; mean \pm SD) of the offered experimental $\operatorname{diets}^{1}$

\begin{tabular}{lcc}
\hline Composition & TMR 1 & TMR 2 \\
\hline Ingredient $_{\text {Corn silage }}{ }^{3}$ & & \\
Haylage $^{3}$ & 23.5 & 23.5 \\
High-moisture corn $^{\text {Protein concentrate pellet }}{ }^{4}$ & 37.7 & 28.9 \\
Grain supplement pellet $^{5}$ & 13.8 & 14.8 \\
Chemical composition & 11.5 & 14.2 \\
DM (\%) & 13.4 & 18.6 \\
OM & $59.5 \pm 6.35$ & $57.9 \pm 1.03$ \\
CP & $91.4 \pm 0.04$ & $91.2 \pm 0.16$ \\
ADF & $18.0 \pm 0.35$ & $18.2 \pm 0.14$ \\
NDF & $24.1 \pm 1.77$ & $22.9 \pm 4.03$ \\
NFC & $35.3 \pm 1.27$ & $35.6 \pm 5.37$ \\
Ca & $38.2 \pm 1.56$ & $37.4 \pm 5.66$ \\
P & $1.1 \pm 0.01$ & $1.1 \pm 0.01$ \\
NE (Mcal/kg of DM) & $0.57 \pm 0.01$ & $0.61 \pm 0.0$ \\
L Chang in forage availabity & $1.6 \pm 0.02$ & $1.6 \pm 0.03$ \\
\hline
\end{tabular}

${ }^{1}$ Changes in forage availability necessitated the use of 2 experimental diets. TMR 1 was fed to the first group of 8 study cows and TMR 2 was fed to the second group of 8 .

${ }^{2}$ Corn silage in TMR 1 had a DM of $38.9 \pm 4.5 \%$ and chemical composition (DM basis) of $8.4 \% \mathrm{CP}, 26.7 \% \mathrm{ADF}$, and $44.2 \% \mathrm{NDF}$. Corn silage in TMR 2 had a DM of $39.7 \pm 1.3 \%$ and chemical composition (DM basis) of $8.4 \% \mathrm{CP}, 25 \% \mathrm{ADF}$, and $42.5 \% \mathrm{NDF}$.

${ }^{3}$ Haylage consisted of red clover (75\%), and timothy/orchard grass (25\%). TMR 1 had a DM of $57.2 \pm 17.4 \%$ and chemical composition (DM basis) of $18.3 \% \mathrm{CP}, 39.2 \% \mathrm{ADF}$, and $50.1 \% \mathrm{NDF}$; TMR 2 had a $\mathrm{DM}$ of $70.9 \pm 4.7 \%$ and chemical composition (DM basis) of $17 \% \mathrm{CP}$, 41.1\% ADF, and $51.7 \% \mathrm{NDF}$.

${ }^{4}$ Supplied by Dundas Feed \& Seed Ltd. (Winchester, ON, Canada) and included the following ingredients (as is): 35 to $40 \%$ corn distillers, 18 to $33 \%$ soybean meal, 8 to $24 \%$ canola, $6.8 \%$ calcium carbonate, 1.5 to $7.5 \%$ feather meal, $2.4 \%$ salt, $2.0 \%$ sodium bicarbonate, 0 to $3 \%$ tallow, $0.8 \%$ dicalcium phosphate, $0.4 \%$ magnesium oxide, $0.144 \%$ trace minerals, and $0.046 \%$ vitamins.

${ }^{5}$ Supplied by Dundas Feed \& Seed Ltd. and included the following ingredients: 20 to $40 \%$ wheat shorts, 16 to $34 \%$ soybean meal, 12 to $32 \%$ corn, 4 to $14 \%$ corn distillers grains, 0 to $10 \%$ oat by-product, $3 \%$ molasses, $2.0 \%$ dry fat, $0.6 \%$ calcium carbonate, $0.9 \%$ dicalcium phosphate, $0.3 \%$ choline chloride, $0.4 \%$ salt, $0.0084 \%$ vitamins, $0.0569 \%$ trace minerals, $1.25 \%$ pellet binder, and $0.125 \%$ flavor/attractant.

${ }^{6}$ Values were obtained from chemical analysis of TMR samples; $\mathrm{OM}=$ $100-\%$ ash $\mathrm{NFC}=100-(\% \mathrm{CP}+\% \mathrm{NDF}+\%$ fat $+\%$ ash $) ; \mathrm{NE}_{\mathrm{L}}$ was calculated based on NRC (2001) equations. outcome variables, including feeding behavior, DMI, and sorting. Estimates of variation for these variables were based on previously reported values (Hosseinkhani et al., 2008; Hart et al., 2013, 2014). Individual cows were categorized by parity as either young ( $\leq$ second lactation) or mature ( $\geq$ third lactation) and assigned to 1 of 4 pairs, in each of the 2 groups. Cows were balanced for DIM and production, and paired to maximize their difference in parity, thus maximizing the effects of competition, as parity has been associated with dominance rank (Val-Laillet et al., 2008). Across the study, mean BW of young cows was $655 \pm 58 \mathrm{~kg}$, and that of mature cows was $738 \pm 66 \mathrm{~kg}$. Seven of the 8 pairs consisted of a young cow matched with a mature cow. Due to an insufficient number of cows in third lactation or greater, 1 of the 8 pairs consisted of a first-lactation cow (designated as young) matched with a second-lactation cow (designated as mature); this maintained a similar difference in parity to the other pairs. In two 10-d periods, pairs of cows were exposed in random order to each of 2 treatments: $2 \times / d$ TMR delivery (low frequency) or $6 \times / \mathrm{d}$ TMR delivery (high frequency). Treatments were assigned alternately to 4 feed bins, with the order reversed between groups. All cows were fed competitively in a ratio of 2 cows: 1 feed bin (i.e., 1 pair of cows per feed bin). Deliveries in the low-frequency treatment occurred at 1545 and $0830 \mathrm{~h}$, and deliveries in the high-frequency treatment occurred at those times plus 4 additional times distributed at 2-h intervals between milkings: 1745, 2100, 1030, and 1230 h (Figure 1).

Three days before the start of the study, each pair was successfully trained to use their assigned feed bin, which was programmed to allow access to only the designated pair of cows. Each pair of cows used the same feed bin for the duration of their time on trial. Treatments were assigned to each pair beginning at the first feeding $(1545 \mathrm{~h})$ on $\mathrm{d} 1$ of each period, and the cows were allowed $5 \mathrm{~d}$ of adaptation before recording began. Data were collected from d 6 to 10 of each treatment

2x/d Feedings
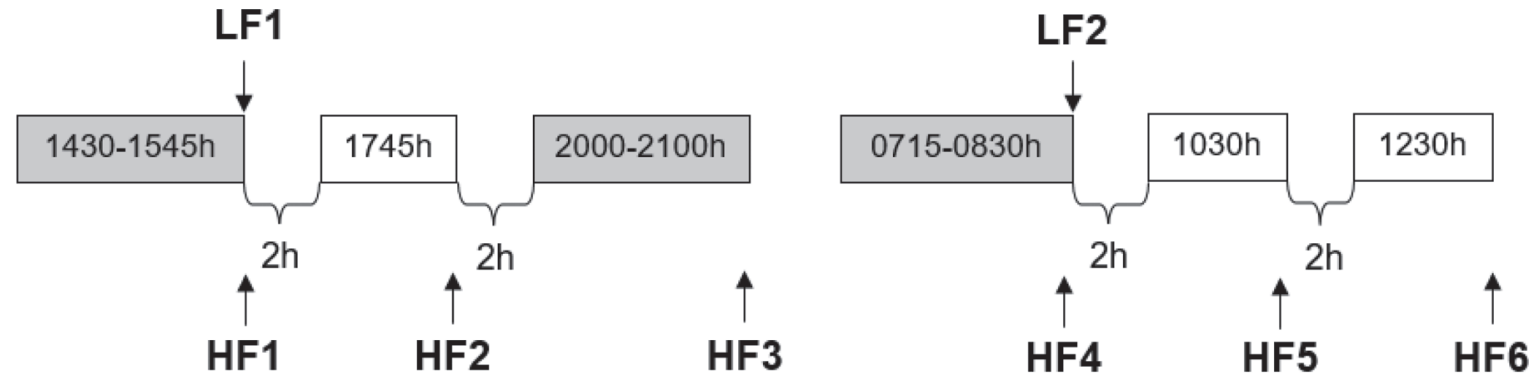

6x/d Feedings

Figure 1. Feed delivery times for cows on the low frequency (LF; $2 \times /$ d delivery), and high frequency (HF; $6 \times /$ d delivery) treatments. Shaded boxes indicate time away for milking, which were identical between treatments. The first feeding of the day after feed bins were cleaned out, for both treatments, followed the afternoon milking starting at $1430 \mathrm{~h}$. 
period beginning daily at $1545 \mathrm{~h}$ and ending at $1544 \mathrm{~h}$ the following day.

\section{Feeding Procedure}

Cows were fed a TMR that met the nutrient requirements, according to NRC (2001), of a cow producing a mean milk yield of $40 \mathrm{~kg} / \mathrm{d}$ (Table 1). Changes in forage availability over time necessitated the use of 2 experimental diets (similar in nutrient composition; Table 1) throughout the course of the study: TMR 1 was fed from the start of the trial until the end of the first group of cows, and TMR 2 was fed starting from the beginning of the second group of cows until the completion of the study. The total amount of feed offered was adjusted daily to target approximately $10 \%$ refusals per bin. Once daily, at approximately $1100 \mathrm{~h}$, TMR was prepared in a mixer wagon (Jaylor 4425; Jaylor Fabricating, Orton, ON, Canada), and transferred to a feed cart (WIC RTM-11; WIC Inc., Wickham, QC, Canada). Supplemental grain pellets were manually weighed on a scale (model 2020; Mettler-Toledo Inc., Mississauga, ON, Canada), added to the TMR in the feed cart, and mixed for approximately $4 \mathrm{~min}$. Sufficient TMR for the first feeding was distributed to the bins, and the remainder stored in covered containers to be delivered at subsequent feedings. All cows were denied access to the bins during milking times until the last cow had exited the AMS (Figure 1) to ensure that all individuals had equal opportunity to access the feed.

\section{Behavioral Data Collection}

Feed bins recorded the time of entry, time of exit, and amount of feed consumed during each visit. These data were used to calculate the average rate of consumption, daily DMI, and daily feeding time of each cow. According to the methods of DeVries et al. (2003b), individual feeding visits were combined into meals using the MIX 3.1.3 software (MacDonald and Green, 1988) to determine meal criteria (the minimum time interval between meals) for all cows. An individual meal criterion for each cow during each treatment period was identified by fitting normal distributions to the frequency of $\log _{10^{-}}$ transformed intervals of time between feeding visits, as recorded by the Insentec system. Meal frequency (no./d) for each cow was determined by summarizing the number of intervals between feeding events that exceeded their meal criterion. Meal length ( $\mathrm{min} / \mathrm{meal})$ was calculated as the time between the start of the first feeding visit and the end of the last visit within the meal criterion. Meal size ( $\mathrm{kg}$ of $\mathrm{DM} /$ meal) was calculated as DMI divided by meal frequency. The length and size of the first meals following all feed deliveries were calculated by summarizing the time spent eating and the total DMI for the first meal after each feed delivery for each cow, averaged across the 5 -d recording period.

The frequency of replacements from the feed bins was recorded according to the methods validated by Huzzey et al. (2014). Feeding visit data collected by the Insentec system were used to determine when one cow (the actor of the replacement) took the place of another (the reactor of the replacement) at the feed bin within $26 \mathrm{~s}$ or less of the reactor's exit from the bin; this action was defined as a replacement. This method of determining replacements is highly correlated $(r=0.94)$ with the common method of measuring displacements from the feed bin (Huzzey et al., 2014). The daily number of replacements for each cow, as either actor or reactor, were summarized and used to calculate a success index (SI) for competitive interactions at the feed bin. The number of times each cow was the actor in a replacement was divided by the number of times they were both the actor and the reactor (Galindo and Broom, 2000; Val-Laillet et al., 2008). An SI value between 0 (low competitive success) and 1 (high competitive success) was obtained for each cow, for each treatment period.

Standing and lying behavioral data were recorded with data loggers (HOBO Pendant G Logger; Onset Computer Corp., Pocasset, MA), as validated by Ledgerwood et al. (2010). Data loggers were secured to the rear hock of individual cows with Vetrap Bandaging Tape (3M, London, ON, Canada) before the start of each recording period (d 6) and removed after $1545 \mathrm{~h}$ on the last day (d 10). Measurements were taken at 1-min intervals and leg orientation data were used to compute lying time (h/d), lying bout frequency (no./d), and bout length (min/bout).

Rumination behavior was electronically monitored using automatic rumination detection loggers (Lely Qwes-HR collars; Lely Industries N.V.), as validated by Schirmann et al. (2009). Rumination time data were processed, summarized in 2-h intervals, and stored for up to $22 \mathrm{~h}$ in the logger's memory; a reader positioned inside the AMS automatically uploaded the stored data at each cow's visit to the milking unit. At the completion of each treatment period, rumination time data were downloaded from the reader and summarized by day and 2-h interval/d for each cow. Rumination per kilogram of DMI per cow was calculated by dividing the daily rumination time for each cow by their daily DMI.

\section{Feed Sampling and Analyses}

Feed samples were collected during the final $5 \mathrm{~d}$ of each period. Two samples of fresh TMR were collected 
daily at the first feeding $(1545 \mathrm{~h})$ to determine DM and sorting. One refusal sample from each pair was collected at the end of each recording day $(1430 \mathrm{~h})$ to determine differences in sorting. Samples of the TMR components were also collected once weekly to be analyzed for DM, chemical composition, and particle size. Upon collection, each sample was frozen at $-15^{\circ} \mathrm{C}$, awaiting further analysis.

All samples were oven-dried at $55^{\circ} \mathrm{C}$ for $48 \mathrm{~h}$; those samples used to determine sorting were separated using a 3-screen (19, 8, $1.8 \mathrm{~mm})$ Penn State Particle Separator (Kononoff et al., 2003) before being dried. Subsequent fractions, as well as whole DM samples, and TMR component samples were ground through a $1-\mathrm{mm}$ screen (Wiley mill; Arthur H. Thomas Co., Philadelphia, PA), in advance of their shipment to Cumberland Valley Analytical Services Inc. (Maugansville, MD) for DM $\left(135^{\circ} \mathrm{C}\right.$; AOAC International, 2000; method 930.15), ash $\left(535^{\circ} \mathrm{C}\right.$; AOAC International, 2000; method 942.05), $\mathrm{ADF}$, and NDF with heat-stable $\alpha$-amylase and sodium sulfite (Van Soest et al., 1991) analyses. Particle size distribution and nutrient composition by particle size fraction are identified in Table 2.

Feed sorting was calculated (according to Leonardi and Armentano, 2003) as the proportion of each fraction actually consumed divided by the proportion that that cow was predicted to consume, expressed as a percentage. Actual DM consumed was determined from the results of the Penn State Particle Separator analysis as the percentage DM of refused feed subtracted from the percentage DM of offered feed for each fraction. Predicted DM consumed was determined as the percentage of total DMI for each particle fraction. The amount of sorting was represented by 3 different categories: a value of $100 \%$ indicated no sorting, a value $>100 \%$ indicated sorting in favor of a particular fraction (actual consumption was greater than predicted), and a value $<100 \%$ indicated sorting against the specified fraction (actual consumption was less than predicted). The greater the difference from $100 \%$, the more the feed was sorted, either for or against that particle size fraction.

\section{Milk Production and Components}

Milk yield was recorded by the AMS for the last 5 $\mathrm{d}$ of each treatment period, and milk composition was recorded by sampling on d 8 and 10; the Lely AMS Shuttle Sampling Device (Lely Industries N.V.) was used to collect a milk sample from each cow at each milking on those days. Resulting milk samples, separate for each cow at each milking, were sent to the DHI testing laboratory (CanWest DHI, Guelph, ON, Canada) for component analysis (fat, protein, and MUN) using a Fourier transform infrared full-spectrum analyzer
Table 2. Particle size distribution ${ }^{1}$ (mean \pm SD), and nutrient content (mean $\pm \mathrm{SD}$ ) by particle size of the offered experimental diets ${ }^{2}$

\begin{tabular}{lrr}
\hline Item & TMR 1 & \multicolumn{1}{c}{ TMR 2 } \\
\hline DM (\%) & $3.5 \pm 0.83$ & $4.9 \pm 1.04$ \\
Long & $38.8 \pm 2.76$ & $43.6 \pm 2.34$ \\
Medium & $38.9 \pm 2.71$ & $34.2 \pm 1.17$ \\
Short & $18.8 \pm 1.26$ & $17.4 \pm 1.95$ \\
Fine & & \\
NDF (\% of screen DM) & $59.9 \pm 0.64$ & $55.0 \pm 1.27$ \\
Long & $38.4 \pm 0.64$ & $37.1 \pm 0.07$ \\
Medium & $36.1 \pm 2.12$ & $33.6 \pm 0.57$ \\
Short & $26.4 \pm 1.56$ & $22.7 \pm 0.49$ \\
Fine & & \\
CP (\% of screen DM) & $8.7 \pm 0.07$ & $10.1 \pm 0.78$ \\
Long & $14.9 \pm 0.21$ & $15.4 \pm 0.57$ \\
Medium & $17.8 \pm 0.00$ & $18.4 \pm 0.49$ \\
Short & $25.0 \pm 0.78$ & $26.2 \pm 0.14$ \\
Fine &
\end{tabular}

${ }^{1}$ Particle size determined by the Penn State Particle Separator, which has a 19-mm screen (long), 8-mm screen (medium), 1.18-mm screen (short), and a pan (fine).

${ }^{2}$ Changes in forage availability necessitated the use of 2 experimental diets. TMR 1 was fed to the first group of 8 study cows and TMR 2 was fed to the second group of 8 .

(Milkoscan FT+ and Milkoscan 6000; Foss, Hillerød, Denmark). One value per cow on each sampling day was obtained by calculating the average across milkings.

Milk composition samples were used to determine $4 \%$ FCM $(\mathrm{kg} / \mathrm{d})$, calculated as $0.4 \times$ milk yield $(\mathrm{kg} / \mathrm{d})+$ $15.0 \times$ fat yield $(\mathrm{kg} / \mathrm{d})(\mathrm{NRC}, 2001)$, and $\mathrm{ECM}(\mathrm{kg} / \mathrm{d})$, calculated as $(0.327 \times \mathrm{kg}$ of milk $)+(12.95 \times \mathrm{kg}$ of fat $)$ $+(7.2 \times \mathrm{kg}$ of protein) (Tyrrell and Reid, 1965). Efficiency of milk production was calculated as kilograms of milk, 4\% FCM yield, and ECM yield per kilogram of DMI per cow.

\section{Statistical Analyses}

All analyses were conducted using SAS software (version 9.4, 2013; SAS Institute Inc., Cary, NC), with significance declared at $P \leq 0.05$, and trends reported if $0.05<P<0.10$. Interactions were considered if they met a significance level of $P \leq 0.05$. Before analysis, data were tested for normality using the UNIVARIATE procedure, and all data met the assumptions of normality. Treatments were applied at the pair level; therefore, pair was considered the experimental unit. Data were summarized by pair and treatment for all outcome variables (feeding time, feeding rate, DMI, feed sorting, rumination time, lying behavior, replacement frequency, and milk production), and compared using a general linear mixed model. The MIXED procedure was used to test for treatment differences. The fixed effects were treatment (low or high frequency), period (1 or 2 ), and the interactions of treatment $\times$ period; 
the random effects were group, and pair within group. The Kenward-Roger adjustment for degrees of freedom was included in the model and all values are reported as least squares means. As diet was confounded with group, the effect of group was initially included in the model as a fixed effect; however, group was determined to be not significant, and thus was included as a random effect. For all measures, variability between individuals within pairs was determined by first calculating the absolute difference within each pair, and averaging over the recording period to provide one value per pair, before comparison in this model.

To determine the occurrence of sorting within treatments, the summarized data for each particle size was tested for a difference from 100 using $t$-tests. Differences in sorting were analyzed using the previously described MIXED procedure model.

The prediction that individual cows within each pair would be differently affected by treatment was tested in another MIXED procedure model with the data summarized at the cow level. The fixed effects were treatment, period, relative parity (young vs. mature), and the interactions of treatment $\times$ period, and treatment $\times$ relative parity, with the Kenward-Roger adjustment for degrees of freedom. Random effects were group and pair within group. No interactions were found between treatment and relative parity; therefore, results of those analyses are not reported. This model was also used to assess the effect of index (SI) on intake patterns (feeding time, feeding rate, and DMI), by replacing the fixed effects of relative parity and treatment $\times$ relative parity, with those of index and the interaction of treatment $x$ index.

\section{RESULTS}

No effect of treatment on DMI, feeding time, or feeding rate was detected (Table 3). A tendency for TMR delivery frequency to affect rumination time was identified, with cows fed $6 \times / \mathrm{d}$ ruminating approximately $25 \mathrm{~min} / \mathrm{d}$ longer than those fed only $2 \times / \mathrm{d}$. Additionally, we detected a tendency toward greater variability in rumination time between cows within pairs under higher frequency of feed delivery [low $=38.0$, high $=$ $50.0 \mathrm{~min} / \mathrm{d}$; standard error of the difference $($ SED $)=$ 5.57; $P=0.08$. Meal patterns were largely unaffected by treatment (Table 3); however, there were discernible differences in the first meal following fresh feed deliveries. Cows had lower feeding time $(P<0.001$; Figure $2 \mathrm{a})$ and DMI $(P<0.001$; Figure $2 \mathrm{~b})$ during the first meal after feed delivery when fed $6 \times /$ d compared with when they were fed $2 \times / d$. No effect of treatment was detected on the variability within pairs for feeding time $(28.1 \mathrm{~min} / \mathrm{d} ; \mathrm{SED}=8.85 ; P=0.68)$, feeding rate $(0.04$ $\mathrm{kg} / \mathrm{min} ; \mathrm{SED}=0.005 ; P=0.88)$, or DMI $(3.88 \mathrm{~kg} / \mathrm{d}$; $\mathrm{SED}=0.93 ; P=0.21$.

Cows sorted the TMR to a similar extent $(P \geq 0.24)$ regardless of the frequency of feed delivery. On average,

Table 3. Effect of frequency of TMR delivery on the feeding behavior, rumination time, and lying behavior of 8 pairs of competitively fed, lactating Holstein dairy cows ${ }^{1}$

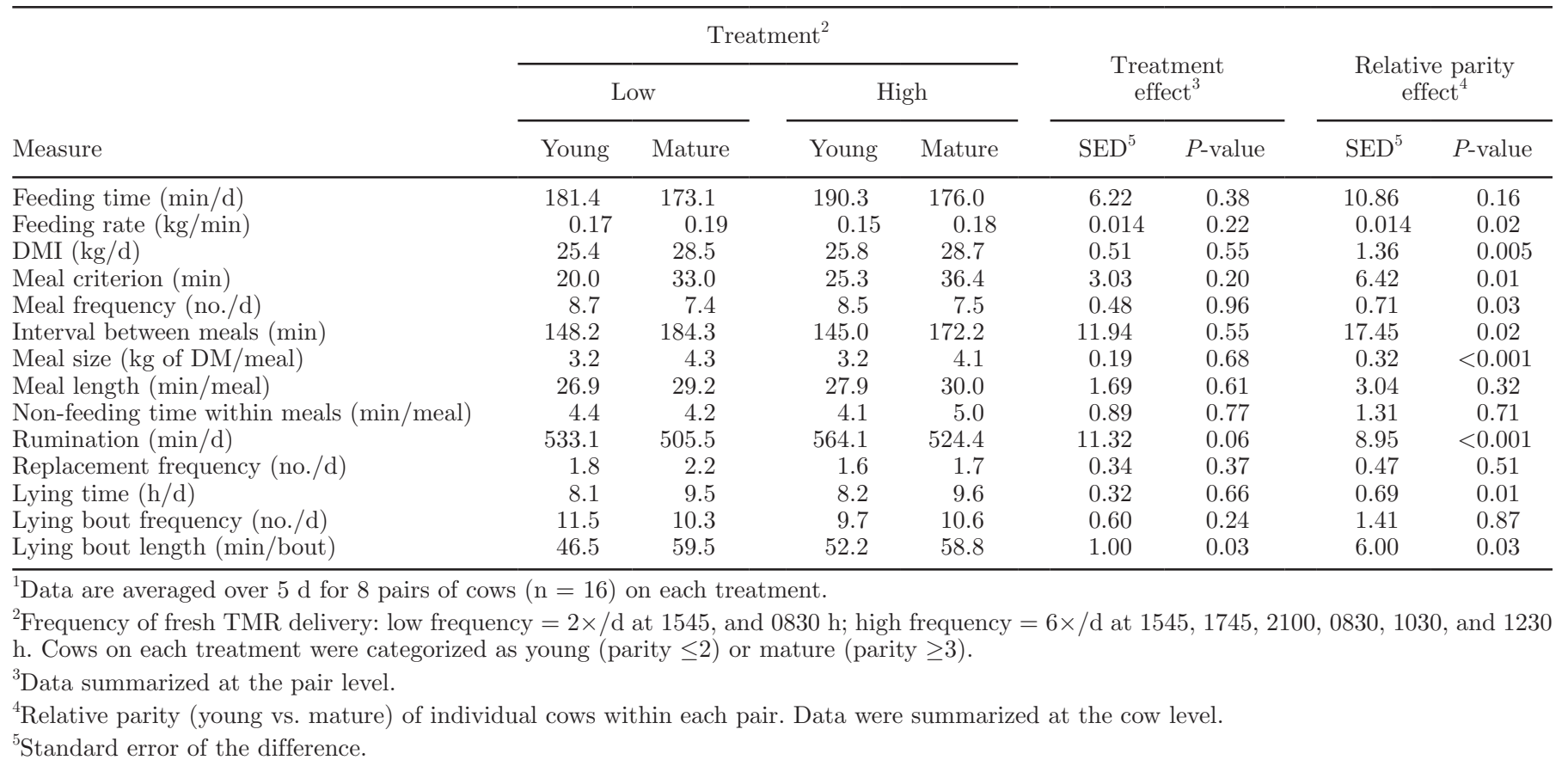



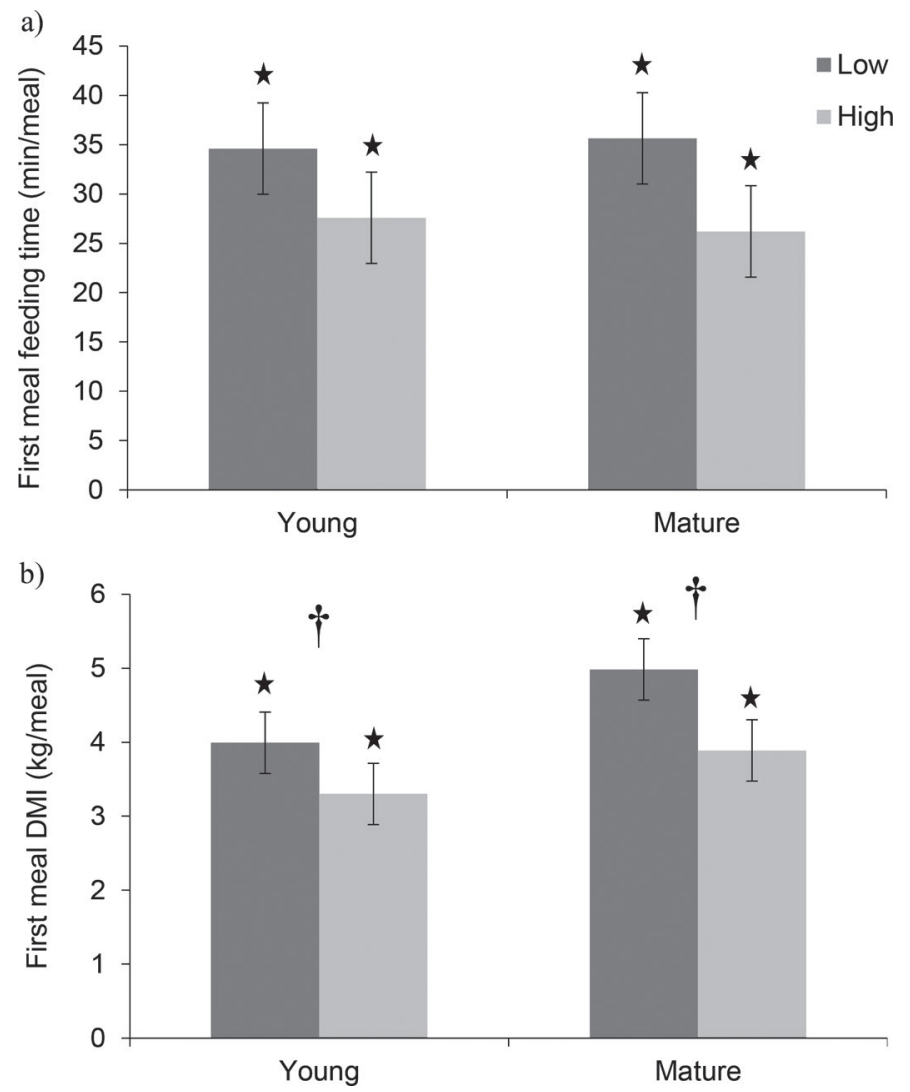

Figure 2. Average (a) feeding time ( $\mathrm{min} /$ meal; mean $\pm \mathrm{SE}$ ), and (b) DMI $(\mathrm{kg} /$ meal; mean $\pm \mathrm{SE})$, for the first meal following all feed deliveries for young (parity $\leq 2$ ) and mature (parity $\geq 3$ ) cows fed at a low $(2 \times / \mathrm{d}$ at 1545 and $0830 \mathrm{~h})$ or high $(6 \times / \mathrm{d}$ at $1545,1745,2100$ 0830, 1030, and $1230 \mathrm{~h}$ ) frequency. All cows were fed competitively in a ratio of 2 cows: 1 feed bin. Data were averaged over $5 \mathrm{~d}$ for 8 pairs of lactating Holstein cows $(\mathrm{n}=16)$ on each treatment. Filled stars indicate significant differences $(P \leq 0.05)$ between treatments, and daggers indicate significant differences between relative parities.

cows did not sort for or against long particles $(98.0 \pm$ $1.5 \% ; P \geq 0.11)$, sorted in favor of medium particles $(104.1 \pm 0.53 \% ; P<0.001)$, and sorted against $(P$ $<0.001)$ both short $(97.9 \pm 0.45 \%)$ and fine $(94.8 \pm$ $0.90 \%)$ particles.

When feeding patterns were compared between young and mature cows, there was a discernible effect of relative parity on feeding rate and DMI, both of which were greater for mature than for young cows (Table 3); however, no effect of relative parity was found on feeding time. An effect of relative parity on meal patterns indicated that meal criteria, meal size, and the interval between meals were all greater for mature cows, whereas meal frequency was lower for mature cows. No effect of relative parity was detected for either meal length or non-feeding time within meals. Yet, a relative parity effect on the first meal after fresh feed delivery was identified; average DMI for the first meals after feed deliveries was lower for young than for mature cows (young $=3.65$; mature $=4.44 \mathrm{~kg}$ of $\mathrm{DM} /$ meal; SED $=0.36 ; P=0.006$; Figure $2 \mathrm{~b}$ ). Young cows demonstrated greater rumination time compared with mature cows (Table 3); additionally, there was an effect of relative parity on rumination time/kilogram of DMI, with young cows ruminating 3.8 min longer than mature cows for every kilogram of DM consumed (young $=21.9$, mature $=18.1 \mathrm{~min} / \mathrm{kg}$ of DMI; SED $=$ $1.11 ; P<0.001)$.

No effect of the frequency of TMR delivery was detected on daily replacement frequency (Table 3), and neither was a difference detected in the variability in daily replacement frequency between pairs (absolute difference of 0.9 replacements $/ \mathrm{d} ;$ SED $=0.97 ; P=$ 0.82). However, there was an effect of SI on feeding patterns, with cows that were more successful in competitive interactions at the feed bins spending a greater amount of time feeding $(P=0.001)$ and having greater DMI $(P=0.009)$ than less successful individuals (data not shown); no effect of SI on feeding rate was detected $(P=0.18)$.

An effect of TMR delivery frequency was detected on the length of lying bouts (Table 3), indicating that lying bouts for cows fed $6 \times / \mathrm{d}$ were an average of 2.5 min longer than for cows fed $2 \times / d$. There was no effect detected on the daily number of lying bouts or total lying time. However, lying time and lying bout length were affected by relative parity, with mature cows lying down longer and demonstrating longer lying bouts than young cows (Table 3); yet no effect of relative parity was observed in the daily lying bout frequency. Greater variability in lying time $(2.0 \mathrm{~h} / \mathrm{d} ; \mathrm{SED}=0.52 ; P=$ $0.96)$, lying bout frequency (3.2 bouts/d; SED $=1.39$; $P=0.29)$, or lying bout length $(16 \mathrm{~min} /$ bout; SED = $5.08 ; P=0.94)$ was not detected within pairs at different frequencies of feed delivery.

Whereas milk production and components appeared unaffected by the frequency of TMR delivery, effects of relative parity were detected (Table 4). Total milk yield, $4 \% \mathrm{FCM}$, and ECM were greater for mature cows than for young cows. Fat yield, protein yield, and MUN were also higher for mature cows. Greater variability within pairs of cows was observed with the low frequency of feed delivery for $4 \%$ FCM, ECM, and protein yields (Table 5), and a tendency was observed for more variability in fat yield. All other milk production variables indicated no effect of treatment.

\section{DISCUSSION}

Under competitive feeding conditions, dairy cattle have been shown to maintain daily DMI by increasing their rate of feed consumption (Olofsson, 1999; Hosse- 
Table 4. Effect of frequency of TMR delivery on milk production and composition for 8 pairs of competitively fed, lactating Holstein dairy cows ${ }^{1}$

\begin{tabular}{|c|c|c|c|c|c|c|c|c|}
\hline \multirow[b]{3}{*}{ Measure } & \multicolumn{4}{|c|}{ Treatment $^{2}$} & \multirow{2}{*}{\multicolumn{2}{|c|}{$\begin{array}{l}\text { Treatment } \\
\text { effect }^{3}\end{array}$}} & \multirow{2}{*}{\multicolumn{2}{|c|}{$\begin{array}{l}\text { Relative parity } \\
\text { effect }^{4}\end{array}$}} \\
\hline & \multicolumn{2}{|c|}{ Low } & \multicolumn{2}{|c|}{ High } & & & & \\
\hline & Young & Mature & Young & Mature & $\mathrm{SED}^{5}$ & $P$-value & $\mathrm{SED}^{5}$ & $P$-value \\
\hline \multicolumn{9}{|l|}{ Milk yield $(\mathrm{kg} / \mathrm{d})$} \\
\hline Milk & 38.8 & 45.7 & 40.0 & 45.6 & 0.45 & 0.27 & 1.98 & $<0.001$ \\
\hline $4 \% \mathrm{FCM}$ & 38.3 & 44.3 & 39.3 & 43.8 & 0.26 & 0.81 & 2.40 & 0.01 \\
\hline Fat & 3.85 & 3.83 & 3.84 & 3.75 & 0.074 & 0.55 & 0.180 & 0.68 \\
\hline Protein & 2.95 & 2.93 & 2.93 & 2.96 & 0.028 & 0.85 & 0.080 & 0.97 \\
\hline \multicolumn{9}{|c|}{ Milk component yield $(\mathrm{kg} / \mathrm{d})$} \\
\hline Fat & 1.52 & 1.74 & 1.55 & 1.69 & 0.048 & 0.91 & 0.110 & 0.04 \\
\hline Protein & 1.17 & 1.33 & 1.18 & 1.34 & 0.026 & 0.81 & 0.083 & 0.01 \\
\hline MUN (mg/dL) & 14.9 & 16.3 & 14.8 & 15.5 & 0.490 & 0.42 & 0.680 & 0.04 \\
\hline \multicolumn{9}{|c|}{ Efficiency of milk production $(\mathrm{kg} / \mathrm{kg})$} \\
\hline
\end{tabular}

${ }^{1}$ Data are averaged over $5 \mathrm{~d}$ (production) or $2 \mathrm{~d}$ (composition) for 8 pairs of cows $(\mathrm{n}=16)$ on each treatment.

${ }^{2}$ Frequency of fresh TMR delivery: low frequency $=2 \times / \mathrm{d}$ at 1545 and $0830 \mathrm{~h}$; high frequency $=6 \times / \mathrm{d}$ at 1545, 1745, 2100, 0830, 1030, and 1230 h. Cows on each treatment were categorized as young (parity $\leq 2$ ) or mature (parity $\geq 3$ ).

${ }^{3}$ Data summarized at the pair level.

${ }^{4}$ Relative parity (young vs. mature) of individual cows within each pair. Data were summarized at the cow level.

${ }^{5}$ Standard error of the difference.

inkhani et al., 2008) and by reducing their total feeding time (Huzzey et al., 2006; Proudfoot et al., 2009) - behavior that could have negative consequences for the health of the animal (Shaver, 2002; Cook et al., 2004). However, in the current study, increasing the frequency of TMR delivery to $6 \times / \mathrm{d}$ from the typical $2 \times / \mathrm{d}$ resulted in no measurable difference in feeding behavior for cows fed competitively. It could be suggested that housing cows on different treatments within the same pen can influence their feeding behavior through social facilitation (Hart et al., 2013), and that cows in the current study on the high-frequency treatment could have altered the behavior of cows on the low-frequency treatment, resulting in the lack of observed differences. However, King et al. (2016a) found that when working with mixed treatment groups, synchrony of feeding behavior of cows on the same treatment was much greater than synchrony of a cow with those on a different treatment.

Table 5. Effect of frequency of TMR delivery on variability ${ }^{1}$ in milk production and composition for 8 pairs of competitively fed, lactating Holstein dairy cows

\begin{tabular}{|c|c|c|c|c|}
\hline \multirow[b]{2}{*}{ Variability measure } & \multicolumn{2}{|c|}{ Treatment $^{2}$} & \multirow[b]{2}{*}{$\mathrm{SED}^{3}$} & \multirow[b]{2}{*}{$P$-value } \\
\hline & Low & High & & \\
\hline \multicolumn{5}{|l|}{ Milk yield $(\mathrm{kg} / \mathrm{d})$} \\
\hline Milk & 8.3 & 7.1 & 0.98 & 0.25 \\
\hline $4 \% \mathrm{FCM}$ & 9.2 & 6.9 & 0.76 & 0.02 \\
\hline ECM & 10.1 & 7.1 & 0.62 & 0.003 \\
\hline \multicolumn{5}{|l|}{ Milk composition (\%) } \\
\hline Fat & 0.44 & 0.37 & 0.12 & 0.58 \\
\hline Protein & 0.19 & 0.21 & 0.062 & 0.82 \\
\hline \multicolumn{5}{|c|}{ Milk component yield $(\mathrm{kg} / \mathrm{d})$} \\
\hline Fat & 0.39 & 0.28 & 0.047 & 0.06 \\
\hline Protein & 0.32 & 0.19 & 0.030 & 0.005 \\
\hline MUN (mg/dL) & 1.66 & 1.45 & 0.530 & 0.70 \\
\hline
\end{tabular}

${ }^{1}$ Absolute difference within each of 8 pairs of cows $(n=16)$, averaged over $5 \mathrm{~d}$ (production) or $2 \mathrm{~d}$ (composition).

${ }^{2}$ Frequency of fresh TMR delivery: low frequency $=2 \times / \mathrm{d}$ at 1545 and $0830 \mathrm{~h}$; high frequency $=6 \times / \mathrm{d}$ at 1545 , $1745,2100,0830,1030$, and $1230 \mathrm{~h}$.

${ }^{3}$ Standard error of the difference. 
Those researchers concluded from their results that the behavioral response to a specific treatment is driven by the treatment they are on more than by the behavior of neighboring cows on a different treatment. Thus, the lack of feeding behavior differences in the current study cannot be attributed primarily to synchrony between treatments. Although daily feeding times numerically increased under the high-frequency treatment, the difference was not significant; similarly, average feeding rate and DMI lacked differences when cows were fed at either low or high frequency. This is consistent with previous research that found no increase in DMI with higher frequency of TMR delivery (Robinson and Sniffen, 1985; Kudrna, 2003; DeVries et al., 2005) and those that found feeding rate to be unaffected by greater feed frequency (Hart et al., 2014). However, there are conflicting results in the literature concerning TMR delivery frequency. In some studies, cows on lower frequencies of feed delivery exhibited greater DMI (Nocek and Braund, 1985; Phillips and Rind, 2001), whereas in others, cows on higher frequencies of feed delivery had greater DMI (Hart et al., 2014). Additionally, greater feeding time has been demonstrated under increased feed delivery frequency in some studies (DeVries et al., 2005; Mäntysaari et al., 2006), whereas others show reduced feeding times (Phillips and Rind, 2001). Thus, determining the precise nature of the changes in feeding behavior under greater feed delivery frequency requires further investigation.

Dominance relationships between individual cows are learned through past interactions and can persist for long periods of time (Bielharz and Zeeb, 1982); therefore, because all cows in the current study were fed competitively ( 2 cows: 1 feed bin), it is possible that this consistent competitive pressure at the feed bin during both the low- and high-frequency treatments maintained the cows' motivation to alter their feeding behavior, regardless of the frequency of TMR delivery. In the current study, pairs consisted of a young and a mature cow to maximize the effect of competition; yet, dominance relationships within a herd can be very complex and do not always follow a linear pattern such that one cow is dominant over all others (Val-Laillet et al., 2008). Thus, it is recommended that future research examine the effect of feed delivery frequency on larger, more socially complex groups of cows that are experiencing high levels of competition for feed access.

Differences in feeding behavior were observed between individual cows within pairs. Mature cows demonstrated greater daily DMI than young cows and consumed feed faster in fewer but larger meals. The difference in DMI is likely attributable to both the greater body size and production level of the mature cows. Previous research has similarly found that mul- tiparous cows at peak production consume larger meals at a faster rate than peak-production primiparous cows (Dado and Allen, 1994). Because social position among herdmates is associated with age, BW, and seniority in the herd (Dickson et al., 1970), it would be expected that younger, subordinate cows would display higher feeding rates when subjected to competitive pressure from herdmates, as demonstrated by previous research (Olofsson, 1999). However, cows categorized as young in the current study included both first- and secondlactation animals, which could have influenced this outcome.

Although we detected no differences in the number of daily replacements or the variability in replacements between treatments, competition for access to feed creates social pressure between individual cows (Nielsen, 1999), resulting in aggressive behavior at the bunk (DeVries et al., 2004; Morgan and Tromborg, 2007). The SI calculated in the current study indicated that as a cow's success in competitive interactions increased, they were able to spend a greater amount of time feeding and achieve greater DMI. This supports previous research by Val-Laillet et al. (2008), who found that cows with high success in competitive interactions spent a greater proportion of their time at the feed bunk than less-successful cows. Researchers have shown that cows selectively consume the high-energy components of the TMR across the day (DeVries et al., 2005), generally sorting in favor of smaller particles and against larger forage particles (Leonardi and Armentano, 2003; DeVries et al., 2007; Hosseinkhani et al., 2008). This could result in an altered composition of the feed available later in the day, as demonstrated by DeVries et al. (2005), who found that the NDF content of the remaining feed increased throughout the day. Whereas those researchers observed the level of sorting to be reduced with TMR delivery frequency of 2 and $4 \times / d$, compared with $1 \times / d$, cows in the current study did not sort differently between low- and high-frequency treatments. This is not surprising when considering that cows exhibited similar feeding rates and time spent feeding between treatments.

Similar to the patterning of feed intakes, no differences in meal patterns across the day were detected between different frequencies of feed delivery. However, examination of the average first meal after each fresh feed delivery did reveal that when cows were fed $6 \times / d$, the first meal was shorter in duration and smaller in size than when cows were fed $2 \times / d$; this behavior was evident for both young and mature cows. It should be noted that the time immediately following fresh feed delivery is of particular interest when studying competitively fed cows, as these are periods of peak feeding activity, when the majority of cows are stimulated to 
feed, and thus the competition for feed bunk access is greatest (DeVries et al., 2003a; DeVries and von Keyserlingk, 2005). These results suggest that implementing feeding management practices such as increased delivery frequency, whereby cows maintain daily DMI while exhibiting shorter and smaller meals during peak periods of feed consumption, could improve access to the bunk during times of high bunk attendance, thereby providing more opportunities for individual cows to consume fresh, unsorted TMR.

The tendency for increased rumination time under high frequency of TMR delivery is supported by the research of Acatincai et al. (2010), who also observed an increase in rumination time when feed delivery was increased from 2 to $3 \times / \mathrm{d}$. This greater rumination time has the potential to positively affect rumen health, as chewing stimulates saliva production, an important factor in sustaining rumen buffering capacity and moderating fluctuations in $\mathrm{pH}$ (Erdman, 1988). This is consistent with research from Shabi et al. (1999), who found that when the feeding frequency of lactating cows was increased from 2 to $4 \times / d$, diurnal fluctuation in ruminal $\mathrm{pH}$ decreased. As the frequency of feed delivery in the current study increased, so too did the variability in rumination time among individuals within pairs, suggesting that not all cows exhibited similar increases. Young cows experienced a numerically greater increase in rumination time between low and high delivery frequency compared with mature cows. Rumination behavior may be reduced under competition for feed access (Batchelder, 2000); thus, the greater increase in rumination time experienced by young cows under increased TMR delivery frequency could indicate a measure of relief from the social pressure imposed by competition with more dominant mature cows for access to feed. As well, mature cows demonstrated higher DMI but ruminated less for every kilogram of DM consumed, thus accounting for the higher overall rumination time of young cows.

Lying behavior is relatively consistent among dairy cows, which tend to modify other behaviors to conserve lying time (Cook et al., 2004; Munksgaard et al., 2005). We observed that when cows were delivered feed at high frequency, they increased each lying bout by 2.5 min; however, because the total number of daily lying bouts did not differ, this had no discernible effect on overall lying time. These findings are contrary to those of DeVries et al. (2005), who found that cows exhibited shorter and more frequent bouts of lying when feed delivery was increased from 2 to $4 \times /$ d. Potentially, the increased competitive pressure at the feed bins in the current study encouraged cows to spend more time lying during each bout, as some overstocked cows have been observed to lie down rather than feed during peak periods (Batchelder, 2000). Mature cows had higher daily lying times than young cows due to longer bouts of lying behavior. This is understandable if you consider young cows to be subordinate individuals, which have been demonstrated to have reduced lying times compared with more dominant cows (Galindo and Broom, 2000).

Consistent with previous research by Hart et al. (2014), we observed no effect of the frequency of feed delivery on milk yields, components, or efficiency. Grant et al. (2015) noted that adaptation periods of 7 to $14 \mathrm{~d}$ are needed in order to detect a response to treatment. Thus, it is possible that our adaptation periods (of $5 \mathrm{~d}$ ) were not long enough to observe a measurable response to treatment. There was, however, notable variation between individual cows within pairs in terms of their milk production. Because production capacity is known to be a major contributing element in the response of a cow to changes in feeding frequency (Grant and Albright, 1995), and physical size is a limiting factor in DMI, and thus production level, it is likely that the difference in BW between mature and young cows influenced this variability in milk production. It is interesting to note that there was less variability between individuals within pairs in $4 \% \mathrm{FCM}, \mathrm{ECM}$, and component yields under the high feeding frequency. This may be explained, in part, by the numerical increase in milk production observed in young cows under the high frequency of TMR delivery. Subordinate cows are most negatively affected by increased competition for feed access (DeVries et al., 2004; Huzzey et al., 2006) but experience the greatest reductions in displacements from the feeding area when fed more often (DeVries et al., 2005). Therefore, it is possible that providing TMR more often in the current study allowed the young cows improved access to feed when they were motivated to, enabling them to ruminate more, and thus reduce the difference in milk production between them and the mature cows.

\section{CONCLUSIONS}

The results of this study suggest that increased frequency of fresh TMR delivery to competitively fed cows may improve access to the feed bunk during periods of peak consumption throughout the day. Allowing cows to consume smaller amounts of TMR over shorter periods, while maintaining daily DMI, would increase access to the feed bunk and provide the opportunity for more cows to feed during peak periods following feed delivery. The results also indicate that relative parity of group-fed cows plays a potentially larger role than the frequency of feed delivery on the behavior and productivity of a cow under competitive pressure, 
and therefore should be taken into consideration when managing groups of competitively fed cows.

\section{ACKNOWLEDGMENTS}

The authors thank all the research and barn staff and students at the University of Guelph, Kemptville Campus, Dairy Education and Innovation Center (Kemptville, ON, Canada). Special thanks go to Victoria Asselstine and Kaitlyn Dancy for their help with feeding and data collection, and to Ben Melenhorst for his technical assistance. This project was financially supported by a Natural Sciences and Engineering Research Council of Canada (NSERC; Ottawa, ON, Canada) Discovery Grant.

\section{REFERENCES}

Acatincai, S., D. Gavojdian, N. Pacala, and L. T. Cziszter. 2010. Relationship between the number of meals per day and rumination process in dairy cows. Lucrari Stiintifice Universitatea de Stiinte Agricole si Med. Vet. Seria Zootehnie 53:336-339.

AOAC International. 2000. Official Methods of Analysis. Vol. I. 17th ed. AOAC International, Arlington, VA.

Batchelder, T. L. 2000. The impact of head gates and over-crowding on production and behaviour patterns of lactating dairy cows. In: Dairy Housing and Equipment Systems. Managing and Planning for Profitability. Natural Resource, Agriculture, and Engineering Service (NRAES) Publ., 129. NRAES, Camp Hill, PA.

Bielharz, R. G., and K. Zeeb. 1982. Social dominance in dairy cattle. Appl. Anim. Ethol. 8:79-97. https://doi.org/10.1016/0304 -3762(82)90134-1.

CCAC. 2009. Guidelines on: The care and use of farm animals in research, teaching and testing. Canadian Council on Animal Care, Ottawa, ON, Canada.

Chapinal, N., D. M. Veira, D. M. Weary, and M. A. G. von Keyserlingk. 2007. Technical note: Validation of a system for monitoring individual feeding and drinking behavior and intake in group housed dairy cows. J. Dairy Sci. 90:5732-5736. https://doi.org/10 $.3168 /$ jds.2007-0331.

Cook, N. B., K. V. Nordlund, and G. R. Oetzel. 2004. Environmental influences on claw horn lesions associated with laminitis and sub-acute ruminal acidosis (SARA) in dairy cows. J. Dairy Sci. 87(E. Suppl.):E36-E46. https://doi.org/10.3168/jds.S0022 $-0302(04) 70059-4$.

Dado, R. G., and M. S. Allen. 1994. Nutrition, feeding and calves. Variation in and relationships among feeding, chewing, and drinking variables for lactating dairy cows. J. Dairy Sci. 77:132-144. https://doi.org/.3168/jds.S0022-0302(94)76936-8.

DeVries, T. J., K. A. Beauchemin, and M. A. G. von Keyserlingk. 2007. Dietary forage concentration affects the feed sorting behavior of lactating dairy cows. J. Dairy Sci. 90:5572-5579. https://doi .org/10.3168/jds.2007-0370.

DeVries, T. J., and M. A. G. von Keyserlingk. 2005. Time of feed delivery affects the feeding and lying patterns of dairy cows. J. Dairy Sci. 88:625-631. https://doi.org/10.3168/jds.S0022-0302(05)72726 -0 .

DeVries, T. J., M. A. G. von Keyserlingk, and K. A. Beauchemin. 2003a. Short communication: Diurnal feeding pattern of lactating dairy cows. J. Dairy Sci. 86:4079-4082. https://doi.org/10.3168/ jds.S0022-0302(03)74020-X.

DeVries, T. J., M. A. G. Von Keyserlingk, and K. A. Beauchemin. 2005. Frequency of feed delivery affects the behavior of lactating dairy cows. J. Dairy Sci. 88:3553-3562. https://doi.org/10.3168/ jds.S0022-0302(05)73040-X.
DeVries, T. J., M. A. G. von Keyserlingk, and D. M. Weary. 2004 Effect of feeding space on the inter-cow distance, aggression, and feeding behavior of free-stall housed lactating dairy cows. J. Dairy Sci. 87:1432-1438. https://doi.org/10.3168/jds.S0022 -0302(04)73293-2.

DeVries, T. J., M. A. G. von Keyserlingk, D. M. Weary, and K. A. Beauchemin. 2003b. Measuring the feeding behavior of lactating dairy cows in early to peak lactation. J. Dairy Sci. 86:3354-3361. https://doi.org/.3168/jds.S0022-0302(03)73938-1.

Dickson, D. P., G. R. Barr, L. P. Johnson, and D. A. Wieckert. 1970. Social dominance and temperament of Holstein cows. J. Dairy Sci 53:904-909. https://doi.org/10.3168/jds.S0022-0302(70)86316-0.

Erdman, R. A. 1988. Dietary buffering requirements of the lactation dairy cows: A review. J. Dairy Sci. 71:3246-3266. https://doi.org/ 10.3168/jds.S0022-0302(88)79930-0.

French, N., and J. J. Kennelly. 1990. Effects of feeding frequency on ruminal parameters, plasma insulin, milk yield, and milk composition in Holstein cows. J. Dairy Sci. 73:1857-1863. https://doi.org/ 10.3168/jds.S0022-0302(90)78866-2.

Galindo, F., and D. M. Broom. 2000. The relationships between social behaviour of dairy cows and the occurrence of lameness in three herds. Res. Vet. Sci. 69:75-79. https://doi.org/10.1053/rvsc.2000 .0391 .

Gibson, J. P. 1984. The effects of frequency of feeding on milk production of dairy cattle: An analysis of published results. Anim. Prod. 38:181-189. https://doi.org/10.1017/S0003356100002178.

Grant, R. J., and J. L. Albright. 1995. Feeding behaviour and management factors during the transition period in dairy cattle. J. Anim. Sci. 73:2791-2803. https://doi.org/10.2527/1995.7392791x.

Grant, R. J., H. M. Dann, and M. E. Woolpert. 2015. Time required for adaptation of behavior, feed intake, and dietary digestibility in cattle. J. Dairy Sci. 98(E. Suppl. 2):312. (Abstr.)

Greter, A. M., R. S. Westerveld, T. F. Duffield, B. W. McBride, T. M. Widowski, and T. J. Devries. 2013. Short communication: effects of frequency of feed delivery and bunk space on the feeding behavior of limit-fed dairy heifers. J. Dairy Sci. 96:1803-1810. https:// doi.org/10.3168/jds.2012-6012.

Hart, K. D., B. W. McBride, T. F. Duffield, and T. J. DeVries. 2013. Effect of milking frequency on the behavior and productivity of lactating dairy cows. J. Dairy Sci. 96:6973-6985. https://doi.org/ 10.3168/jds.2013-6764.

Hart, K. D., B. W. McBride, T. F. Duffield, and T. J. DeVries. 2014. Effect of frequency of feed delivery on the behavior and productivity of lactating dairy cows. J. Dairy Sci. 97:1713-1724. https://doi .org $/ 10.3168 /$ jds.2013-7504.

Hosseinkhani, A., T. J. DeVries, K. L. Proudfoot, R. Valizadeh, D. M. Veira, and M. A. G. von Keyserlingk. 2008. The effects of feed bunk competition on the feed sorting behavior of close-up dry cows. J. Dairy Sci. 91:1115-1121. https://doi.org/10.3168/jds .2007-0679.

Huzzey, J. M., T. J. DeVries, P. Valois, and M. A. G. von Keyserlingk. 2006. Stocking density and feed barrier design affect the feeding and social behavior of dairy cattle. J. Dairy Sci. 89:126-133. https://doi.org/10.3168/jds.S0022-0302(06)72075-6.

Huzzey, J. M., D. M. Weary, B. Y. F. Tiau, and M. A. G. von Keyserlingk. 2014. Short communication: Automatic detection of social competition using an electronic feeding system. J. Dairy Sci. 97:2953-2958. https://doi.org/10.3168/jds.2013-7434.

King, M. T. M., R. E. Crossley, and T. J. DeVries. 2016a. Synchronization of dairy cows does not limit the behavioral response to treatment in mixed treatment experimental designs. Front. Vet. Sci. 3:98.

King, M. T. M., R. E. Crossley, and T. J. DeVries. 2016b. Impact of timing of feed delivery on the behavior and productivity of dairy cows. J. Dairy Sci. 99:1471-1482. https://doi.org/10.3168/jds.2015 $-9790$.

Kononoff, P. J., A. J. Heinrichs, and D. R. Buckmaster. 2003. Modification of Penn State forage and total mixed ration particle separator and the effects of moisture content on its measurement. J. Dairy Sci. 86:1858-1863. https://doi.org/10.3168/jds.S0022 -0302(03)73773-4. 
Krause, K. M., and G. R. Oetzel. 2006. Understanding and preventing subacute ruminal acidosis in dairy herds: A review. Anim. Feed Sci. Technol. 126:215-236. https://doi.org/10.1016/j.anifeedsci .2005.08.004.

Kudrna, V. 2003. Effect of different feeding frequency employing total mixed ration (TMR) on dry matter intake and milk yield in dairy cows during the winter. Acta Vet. Brno 72:533-539.

Ledgerwood, D. N., C. Winckler, and C. B. Tucker. 2010. Evaluation of data loggers, sampling intervals, and editing techniques for measuring the lying behavior of dairy cattle. J. Dairy Sci. 93:51295139. https://doi.org/10.3168/jds.2009-2945.

Leonardi, C., and L. E. Armentano. 2003. Effect of quantity, quality, and length of alfalfa hay on selective consumption by dairy cows. J. Dairy Sci. 86:557-564. https://doi.org/10.3168/jds.S0022 -0302(03)73634-0.

Leonardi, C., and L. E. Armentano. 2007. Short communication: Feed selection by dairy cows fed individually in a tie-stall or as a group in a free-stall barn. J. Dairy Sci. 90:2386-2389. https://doi.org/10 $.3168 /$ jds.2006-537.

MacDonald, P. D. M., and P. E. J. Green. 1988. User's Guide to Program MIX: An interactive program for fitting mixtures of distributions. Release 2.3, January 1988. Ichthus Data Systems, Hamilton, ON, Canada.

Mäntysaari, P., H. Khalili, and J. Sariola. 2006. Effect of feeding frequency of a total mixed ration on the performance of high-yielding dairy cows. J. Dairy Sci. 89:4312-4320. https://doi.org/10.3168/ jds.S0022-0302(06)72478-X.

Miller-Cushon, E. K., and T. J. DeVries. 2017. Feed sorting in dairy cattle: Causes, consequences, and management. J. Dairy Sci. 100:4172-4183. https://doi.org/10.3168/jds.2016-11983.

Morgan, K. N., and C. T. Tromborg. 2007. Sources of stress in captivity. Appl. Anim. Behav. Sci. 102:262-302. https://doi.org/10 .1016/j.applanim.2006.05.032.

Morris, T. R. 1999. Experimental Design and Analysis in Animal Sciences. CABI Publishing, New York, NY.

Munksgaard, L., M. B. Jensen, L. J. Pedersen, S. W. Hansen, and L. Matthews. 2005. Quantifying behavioural priorities - Effects of time constraints on behaviour of dairy cows, Bos taurus. Appl. Anim. Behav. Sci. 92:3-14. https://doi.org/10.1016/j.applanim .2004.11.005.

Nielsen, B. L. 1999. On the interpretation of feeding behaviour measures and the use of feeding rate as an indicator of social constraint. Appl. Anim. Behav. Sci. 63:79-91. https://doi.org/10 .1016/S0168-1591(99)00003-9.

Nocek, J. E., and J. E. Braund. 1985. Effect of feeding frequency on diurnal dry matter consumption, liquid dilution rate, and milk yield in first lactation. J. Dairy Sci. 198:2238-2247. https://doi .org/10.3168/jds.S0022-0302(85)81096-1.
NRC. 2001. Nutrient Requirements for Dairy Cattle. 7th rev. ed. Natl. Acad. Sci. Washington, DC.

Olofsson, J. 1999. Competition for total mixed diets fed for ad libitum intake using one or four cows per feeding station. J. Dairy Sci. 82:69-79. https://doi.org/10.3168/jds.S0022-0302(99)75210-0.

Phillips, C. J., and M. I. Rind. 2001. The effects of frequency of feeding a total mixed ration on the production and behavior of dairy cows. J. Dairy Sci. 84:1979-1987. https://doi.org/10.3168/jds .S0022-0302(01)74641-3.

Proudfoot, K. L., D. M. Veira, D. M. Weary, and M. A. G. von Keyserlingk. 2009. Competition at the feed bunk changes the feeding, standing, and social behavior of transition dairy cows. J. Dairy Sci. 92:3116-3123. https://doi.org/10.3168/jds.2008-1718.

Rioja-Lang, F. C., D. J. Roberts, S. D. Healy, A. B. Lawrence, and M. J. Haskell. 2009. Dairy cows trade-off feed quality with proximity to a dominant individual in Y-maze choice tests. Appl. Anim. Behav. Sci. 117:159-164. https://doi.org/10.1016/j.applanim.2008 .12 .003 .

Robinson, P. H., and C. J. Sniffen. 1985. Forestomach and whole tract digestibility for lactating dairy cows as influenced by feeding frequency. J. Dairy Sci. 68:857-867. https://doi.org/10.3168/jds .S0022-0302(85)80903-6.

Schirmann, K., M. A. G. von Keyserlingk, D. M. Weary, D. M. Veira, and W. Heuwieser. 2009. Technical note: Validation of a system for monitoring rumination in dairy cows. J. Dairy Sci. 92:6052-6055. https://doi.org/10.3168/jds.2009-2361.

Shabi, Z., I. Bruckental, and S. Zamwell. 1999. Effects of extrusion of grain and feeding frequency on rumen fermentation, nutrient digestibility, and milk yield and composition in dairy cows. J. Dairy Sci. 82:1252-1260. https://doi.org/10.3168/jds.S0022 $-0302(99) 75348-8$

Shaver, R. D. 2002. Rumen acidosis in dairy cattle: Bunk management considerations. Adv. Dairy Technol. 14:241-249.

Tyrrell, H. F., and J. T. Reid. 1965. Prediction of the energy value of cow's milk. J. Dairy Sci. 48:1215-1223. https://doi.org/10.3168/ jds.S0022-0302(65)88430-2.

Val-Laillet, D., A. M. de Passillé, J. Rushen, and M. A. G. von Keyserlingk. 2008. The concept of social dominance and the social distribution of feeding-related displacements between cows. Appl. Anim. Behav. Sci. 111:158-172. https://doi.org/10.1016/j applanim.2007.06.001

Van Soest, P. J., J. B. Robertson, and B. A. Lewis. 1991. Methods for dietary fiber, neutral detergent fiber and non-starch polysaccharide in relation to animal nutrition. J. Dairy Sci. 74:3583-3597. https://doi.org/10.3168/jds.S0022-0302(91)78551-2.

Wierenga, H. K. 1990. Social dominance in dairy cattle and the influences of housing and management. Appl. Anim. Behav. Sci. $27: 201-229$. 